\title{
Darwinula oryzalis nom. nov.-A New Replacement Name for the Preoccupied Specific Name Darwinula acuta Mishina, 1966 (Ostracoda)
}

\author{
M. A. Naumcheva ${ }^{a, b}$, * \\ ${ }^{a}$ Borissiak Paleontological Institute, Russian Academy of Sciences, Moscow, 117647 Russia \\ ${ }^{b}$ Moscow State University, Moscow, 119991 Russia \\ *e-mail: zhokina@paleo.ru \\ Received March 28, 2018
}

DOI: $10.1134 / \mathrm{S} 003103011805009 \mathrm{X}$

Mishina (1966) described a new ostracod species, Darwinula acuta, from the Lower Triassic of the Kostroma Region (Mishina, 1966, text-fig. 3, fig. 2). However this name had been previously used for Darwinula acuta Lev, 1957 from the Upper Permian Deposits of the Nordvick District, Krasnoyarsk Region (Lev, 1957). According to Article 60.3 of the ICZN Code, a junior primary homonym should be replaced by a new replacement name (International..., 1999; Mezhdunarodnyi..., 2004). The name Darwinula oryzalis nom. nov. (from the Latin oryza (rice)) is hereby proposed as a replacement name. The holotype of $D$. acuta Mishina, 1966 is housed in the Lower Volga Scientific Research Institute of Geology and Geophysics, Saratov, specimen no. 2-07, complete shell; Kostroma Region, village of Shiryaekha, Borehole 4, depth 88.6-89.4 m; Lower Triassic, Induan, Vetluga Group, Vokhma Formation.

\section{ACKNOWLEDGMENTS}

The study was supported by the Russian Foundation for Basic Research, project nos. 16-04-01062, 17-04-00410, 17-04-01937, 18-34-00721.

\section{REFERENCES}

Lev, O.M., Ostracods from the Misailap and Effuzivnotufovaya formations of the Upper Permian in the Nordvik region, Tr. Nauchno-Issled. Inst. Geol. Arkt., 1957, vol. 4, no. 7, pp. 24-35.

International Code of Zoological Nomenclature: Fourth Edition, International Trust for Zoological Nomenclature, 1999.

Mezhdunarodnyi kodeks zoologicheskoi nomenklatury: Izdanie chetvertoe (International Code of Zoological Nomenclature: Fourth Edition), Moscow: KMK, 2004.

Mishina, E.M., A detailed ostracod-based stratigraphy of the Vetluga Group (Lower Triassic), Izv. Akad. Nauk SSSR. Ser. Geol., 1966, no. 12, pp. 95-112.

Translated by S. Nikolaeva 